\title{
STUDY OF THE SPECIFIC ACTIVITY OF THE PHYTOCOMPOSITION ON THE DEXAMETHASONE-INDUCED INSULIN RESISTANCE
}

Introduction. Type 2 diabetes mellitus (DM2) has recently become an epidemic in the population. There are approximately 463 million patients in the world, and according to experts from the International Diabetes Federation, it is expected to increase to 700 million people by 2045, of which more than $90 \%$ will fall on DM2. Despite the significant progress made in studying the pathogenesis of DM, the presence of a wide range of antidiabetic drugs, diabetes remains an acute medical and social problem.

The aim of the study - to investigate the specific activity of the phytocomposition, which contains dry extracts of white mulberry leaves (Morus alba L.), common beans shells (Phaseolus vulgaris L.), bilberry sprouts (Vaccinium myrtillus L.) in the experimental model of insulin resistance caused by dexamethasone injections.

Research Methods. The experiments were performed on male rats aged three months and weight (200 \pm 20$) \mathrm{g}$. Experimental animals were divided into the following groups: negative and positive control, two reference groups, which received Arfazetin and metformin respectively, and experimental group, which received phytocomposition. Insulin resistance was modeled by intramuscular administration of glucocorticosteroid dexamethasone $(0.125 \mathrm{mg} / \mathrm{kg}$ daily for 13 days in the morning). The state of glucose homeostasis was assessed by changes in basal glycemia and under oral glucose tolerance test, short insulin and adrenalin test. Functional glycemic coefficients were also calculated. Statistical processing was performed using computer programs IBM SPSS Statistics v.10.1 and MS Excel 2010.

Results and Discussion. Basal glycemia after modeling insulin resistance in the experimental group, which received the phytocomposition, was significantly lower by $19.0 \%$ from the positive control group and did not differ from the activity of metformin. During the oral glucose tolerance test, the phytocomposition significantly inhibited the growth of glycemia in all studied periods relative to the indicators of the positive control group. Functional glycemic coefficients, which were obtained based on test data, did not exceed the norm. Insulin sensitivity under the influence of phytomedicine increased by $16.2 \%$ above the positive control group, indicating inhibition of insulin resistance development under its influence. The studied phytocomposition inhibited the development of adrenaline glycemia by $42.9,70.2 \%$ after 30 and $90 \mathrm{~min}$, respectively, relative to the positive control group, which corresponds to the indicators of the negative control group and reference group, which received Arfazetin, but this decrease is not enough to exceed the effect of metformin.

Conclusions. The obtained results indicate that the studied phytocomposition inhibits the development of insulin resistance and carbohydrate tolerance in the conditions of insulin resistance caused by the introduction of dexamethasone.

KEY WORDS: diabetes mellitus; insulin resistance; hypoglycemic activity; white mulberry; common bean; bilberry.

INTRODUCTION. Type 2 diabetes mellitus (DM2) has recently become an epidemic in the population. There are approximately 463 million patients in the world, and according to experts from the International Diabetes Federation, it is expected to increase to 700 million people by 2045 , of which more than $90 \%$ will fall on DM2 [1]. Progressive hyperglycemia, which develops in patients with DM, stimulates various glycolysis-dependent pathological pathways, potentially contributes to tissue damage. Causing destruction of pancreatic cells, reduced insulin synthesis, and secretion, (c) A. I. Dub, I. M. Klishch, L. V. Vronska, I. P. Stechyshyn, 2021. reduces insulin sensitivity of peripheral head tissues, and causes the development of complications of DM. The combination of insulin resistance (IR) and hyperinsulinemia is the starting point for many metabolic disorders [2].

The goal of treating patients with DM2 is to achieve the maximum reduction of the total risk of complications by achieving and maintaining the target level of metabolic parameters [3]. Traditional tactics for the treatment of DM2 involve a gradual transition from diet therapy and lifestyle changes to drug therapy, which, in turn, necessarily involves the use of antidiabetic drugs (oral drugs or insulin) 
[2]. However, in DM of both types, an important role is played by the prescription of drugs, which is directly aimed at correcting metabolic processes. Without diminishing the role of synthetic drugs, it should be noted that plants have polyvalent properties, mild but at the same time long-lasting. Today, herbal medicine is becoming an essential part of the treatment of patients with DM. It can be used for certain types and stages of the disease as monotherapy combined with diet therapy and adjunctive therapy, given the importance of preventing complications in DM - in combination with antihyperglycemic agents and insulin [4].

Despite the significant progress made in studying the pathogenesis of DM, the presence of a wide range of antidiabetic drugs, diabetes remains an acute medical and social problem. Therefore, based on the above, the search for new herbal medicines that could be used with dignity in medical practice remains relevant.

Several promising plants were selected to create a phytocomposition, namely white mulberry, beans, and bilberry, the hypoglycemic and hypolipidemic properties confirmed in previous studies $[5,6]$.

The aim of the study - to investigate the specific activity of the phytocomposition, which contains dry extracts of white mulberry leaves (Morus alba L.), common beans shells (Phaseolus vulgaris L.), bilberry sprouts (Vaccinium myrtillus L.) in the experimental model of insulin resistance caused by dexamethasone injections.

RESEARCH METHODS. The experiments were performed on male rats aged three months and weight $(200 \pm 20) \mathrm{g}$ with normal carbohydrate homeostasis, which was assessed by basal glycemia.

Experimental animals were divided into the following groups:

1-2 - Negative control (NC) $(n=8)$, Positive control $(P C)(n=10)$ - received an equivalent amount of distilled water as a placebo.

3-4 - Reference group, that received infusion of the plant collection Arfazetin $(n=10)(12 \mathrm{ml} / \mathrm{kg})$ ("Liktravy", Ukraine) and a suspension of synthetic hypoglycemic agent metformin $(\mathrm{n}=10)(150 \mathrm{mg} / \mathrm{kg})$ ("Diaformin", "Farmak", Ukraine). Doses were calculated according to the instructions for the drugs use, taking into account the coefficient of species endurance according to Yu. Yu. Rybolovliev [7].

5 - Experimental group $(n=10)$ - received phytocomposition at a dosage of $100 \mathrm{mg} / \mathrm{kg}$ based on a dry extract of white mulberry leaves, which was experimentally determined in previous studies [8].

Oral administration of distilled water, Arfazetin infusion, metformin suspension, and an aqueous solution of phytocomposition were performed intragastrically through a thin metal atraumatic probe simultaneously with dexamethasone injections.

Insulin resistance (IR) was modeled by intramuscular administration to rats of groups $2-5$ of glucocorticosteroid dexamethasone ("KRKA Ukraine", Slovenia) at a dose of $0.125 \mathrm{mg} / \mathrm{kg}$ daily for 13 days in the morning. This regimen in young rats leads to the development of glucose intolerance, IR, and hyperinsulinemia, but unlike older rats does not cause changes in basal glycemia, i.e., reproduces the state of prediabetes [8].

Blood for research was obtained from the tail vein of rats by distal resection of the tail. The concentration of glucose in the blood was determined by the biosensor electrochemical method (using test strips, glucometer "Accu-Chek Performa Nano" ("Roche Diagnostics", Germany)). The glucose level in the blood was determined on an empty stomach to avoid the effect of food on the absorption of the studied drugs and expressed in absolute and relative values. The first determination was performed before the start of the experiment, and the second was after inducing the IR and introducing appropriate solutions. The state of glucose homeostasis was assessed by changes in basal glycemia, using an oral glucose tolerance test (OGTT) and a short insulin test.

Under OGTT [7], all groups of animals were subjected to "glucose load" by intragastric administration of $40 \%$ glucose solution (based on glucose $3 \mathrm{~g} / \mathrm{kg}$ body weight). After 30, 60, 90, 120, and $180 \mathrm{~min}$, the blood glucose level of all groups' animals was determined [5].

Functional glycemic coefficients were also calculated, which is considered to be no less important than detecting the dynamics of changes in glucose concentration after its introduction [9-11]:

Hyperglycemic Baudouin's coefficient (BC) the ratio of glucose levels after $60 \mathrm{~min}$ to basal glycemia; normally less than 1.7;

Postglycemic (hypoglycemic) Rafalsky's coefficient (RC) - the ratio of the patient's blood glucose level after 120 minutes to basal glycemia); normally less than 1.3;

Sokolnikov's coefficient (SC) - the ratio of the difference between the maximum and basal to the difference between the maximum and minimum glycemia; normally less than or equal to 1.0.

The sensitivity of peripheral tissues to the action of insulin was studied in the short insulin test, the result of which was presented as the insulin sensitivity coefficient, which shows the percentage reduction in glycemia 30 min after intraperitoneal administration of exogenous insulin (1 MU/kg body weight, "Actrapid" "Novo Nordisk", Denmark)) regarding basal glycemia (after night fasting) [7]. 
The state of carbohydrate reserves in the body was assessed by the degree and rate of rising of the glycemic curve in the adrenaline test by intramuscular injection of $0.18 \%$ solution of adrenaline hydrotartrate a dose of $0.5 \mathrm{mg} / \mathrm{kg}$ (based on adrenaline hydrochloride). After 30 and 90 minutes, the blood glucose concentration was determined [12-13].

All manipulations were carried out following the general ethical principles of animal experiments, regulated by the provisions of the European Convention for the Protection of Vertebrate Animals Used for Experimental and other Scientific Purposes (European Convention for the Protection of Vertebrate Animals used for Experimental and other Scientific Purposes, Strasbourg, 1986, as amended, 1998) and the Law of Ukraine "On the Protection of Animals against Cruel Treatment" (No. 1759-VI of December 15, 2009) and the EU Directive 2010/10/63 EU on animal experiments.

Statistical processing of the results was performed by methods of variation statistics using Mann-Whitney U-test and Student's test using computer programs IBM SPSS Statistics v.10.1, and MS Excel 2010 and presented as comparative tables with the results of different groups. To assess the probability of the obtained results took the significance level $p \leq 0.05$.

RESULTS AND DISCUSSION. Before starting IR modeling, basal glycemia of different groups did not differ significantly (Table 1 ). Still, after 13 days of dexamethasone administration, it is possible to notice its growth in the PC group by $27.6 \%$, in the reference group, which received Arfazetin and metformin - by 12.8 and $6.4 \%$, respectively.
In the experimental group, which received phytocomposition, fasting glucose concentration increased by $8.6 \%$, significantly lower by $19.0 \%$ than the PC group. However, according to modern criteria for the diagnosis of DM [14], the rate of basal glycemia in venous blood is - 4.0-6.1 mmol/l, which does not indicate the development of carbohydrate metabolism in groups $2-5$, which were administered dexamethasone.

Carbohydrate tolerance tests allow correctly assessing the therapeutic effect of the compound on glucose utilization, which is especially important in the absence of a significant impact on basal glucose blood levels [7].

It is known that the "glucose load" test (OTTG) since 1999 is considered the "gold standard" for the diagnosis of not only DM but also the detection of carbohydrate metabolism disorders [15].

During the OTTG, the following data were obtained, presented in Table 2.

In the analysis of the obtained values (Table 2), it was taken into account that the first rise in glucose levels after oral administration reflects the strength of the reflex stimulation of the sympathetic nerves, which occurs when glucose enters the gastrointestinal tract. Thus, in healthy individuals, 15-20 minutes after glucose intake, there is an increase in blood glucose concentration, which reaches its maximum up to $60 \mathrm{~min}$, which is associated with the rate of carbohydrate absorption (determined, in particular, the condition of the intestinal wall) and liver function [9-10]. After that, the glucose level begins to fall, and up to 120 minutes of observation, the blood glucose concentration should be below $7.8 \mathrm{mmol} / \mathrm{l}$ (for capillary blood) and $6.7 \mathrm{mmol} / \mathrm{l}$ (for venous blood) $[14,16]$, and after 150-180 min

Table 1 - The changes in basal glycemia before and after inducing insulin resistance

\begin{tabular}{||l|c|c|}
\hline \multirow{2}{*}{ Experimental group } & \multicolumn{2}{|c|}{ The basal glycemia, $\mathrm{mmol} / \mathrm{l}$} \\
\cline { 2 - 3 } & Before the injection & After the injection \\
\hline Negative control (NC) & $4.71 \pm 0.19$ & $4.50 \pm 0.15$ \\
\hline Positive control (PC) & $4.65 \pm 0.09$ & $5.91 \pm 0.10$ \\
\cline { 2 - 3 } & $\mathrm{p}_{1}>0.10$ & $\mathrm{p}_{1} \leq 0,001$ \\
\hline Reference group (Arfazetin) & $4.73 \pm 0.15$ & $5.32 \pm 0.13$ \\
\cline { 2 - 3 } & $\mathrm{p}_{1}>0.10$ & $\mathrm{p}_{1} \leq 0.001$ \\
\cline { 2 - 3 } & $\mathrm{p}_{2}>0.10$ & $\mathrm{p}_{2} \leq 0.01$ \\
\hline Reference group (Metformin) & $4.70 \pm 0.10$ & $5.00 \pm 0.11$ \\
\cline { 2 - 3 } & $\mathrm{p}_{1}>0.10$ & $\mathrm{p}_{1} \leq 0.05$ \\
\cline { 2 - 3 } & $\mathrm{p}_{2}>0.10$ & $\mathrm{p}_{2} \leq 0.001$ \\
\hline \multirow{3}{*}{$\begin{array}{l}\text { Experimental group } \\
\text { (Phytocomposition) }\end{array}$} & $4.64 \pm 0.0$ & $5.03 \pm 0.08$ \\
\cline { 2 - 3 } & $\mathrm{p}_{1}>0.10$ & $\mathrm{p}_{1} \leq 0.01$ \\
\cline { 2 - 3 } & $\mathrm{p}_{2}>0.10$ & $\mathrm{p}_{2} \leq 0.001$ \\
\cline { 2 - 3 } & $\mathrm{p}_{3}>0.10$ & $\mathrm{p}_{3} \leq 0.10$ \\
\cline { 2 - 3 } & $\mathrm{p}_{4}>0.10$ & $\mathrm{p}_{4}>0.10$ \\
\cline { 2 - 3 } & &
\end{tabular}

Note. $\mathrm{p}_{1}-$ significantly relative to the NC group;

$\mathrm{p}_{2}$ - significantly relative to the PC group;

$\mathrm{p}_{3}$ - significantly relative to the reference group (Arfazetin);

$\mathrm{p}_{4}$ - significantly relative to the reference group (Metformin). 
Table 2 - The results of oral glucose tolerance test (OGTT)

\begin{tabular}{||l|c|c|c|c|c|c||}
\hline \multirow{2}{*}{ Experimental group } & The basal & \multicolumn{5}{|c|}{ The blood glucose concentration, mmol/l } \\
\cline { 3 - 7 } glycemia, mmol/l & after $30 \mathrm{~min}$ & after 60 min & after 90 min & after 120 min & after $180 \mathrm{~min}$ \\
\hline Negative control (NC) & $4.5 \pm 0.15$ & $6.68 \pm 0.21$ & $7.03 \pm 0.18$ & $6.30 \pm 0.17$ & $5.59 \pm 0.12$ & $4.44 \pm 0.08$ \\
\hline Positive control (PC) & $5.91 \pm 0.10$ & $10.54 \pm 0.12$ & $10.82 \pm 0.16$ & $9.82 \pm 0.10$ & $8.64 \pm 0.11$ & $6.32 \pm 0.06$ \\
& $p_{1} \leq 0.001$ & $p_{1} \leq 0.001$ & $p_{1} \leq 0.001$ & $p_{1} \leq 0.001$ & $p_{1} \leq 0.001$ & $p_{1} \leq 0.001$ \\
\hline Reference group & $5.32 \pm 0.13$ & $8.90 \pm 0.18$ & $9.32 \pm 0.12$ & $8.09 \pm 0.14$ & $7.07 \pm 0.17$ & $5.29 \pm 0.10$ \\
(Arfazetin) & $p_{1} \leq 0.001$ & $p_{1} \leq 0.001$ & $p_{1} \leq 0.001$ & $p_{1} \leq 0.001$ & $p_{1} \leq 0.001$ & $p_{1} \leq 0.001$ \\
& $p_{2} \leq 0.01$ & $p_{2} \leq 0.001$ & $p_{2} \leq 0.001$ & $p_{2} \leq 0.001$ & $p_{2} \leq 0.001$ & $p_{2} \leq 0.001$ \\
\hline Reference group & $5.00 \pm 0.11$ & $7.68 \pm 0.10$ & $7.99 \pm 0.10$ & $7.34 \pm 0.09$ & $6.44 \pm 0.07$ & $5.07 \pm 0.08$ \\
(Metformin) & $p_{1} \leq 0.05$ & $p_{1} \leq 0.001$ & $p_{1} \leq 0.001$ & $p_{1} \leq 0.001$ & $p_{1} \leq 0.001$ & $p_{1} \leq 0.001$ \\
& $p_{2 \leq} 0.001$ & $p_{2} \leq 0.001$ & $p_{2} \leq 0.001$ & $p_{2} \leq 0.001$ & $p_{2} \leq 0.001$ & $p_{2} \leq 0.001$ \\
\hline Experimental group & $5.03 \pm 0.08$ & $7.90 \pm 0.17$ & $7.96 \pm 0.11$ & $7.02 \pm 0.11$ & $6.41 \pm 0.13$ & $4.99 \pm 0.04$ \\
(Phytocomposition) & $p_{1} \leq 0.01$ & $p_{1} \leq 0.001$ & $p_{1} \leq 0.001$ & $p_{1} \leq 0.01$ & $p_{1} \leq 0.001$ & $p_{1} \leq 0.001$ \\
& $p_{2} \leq 0.001$ & $p_{2} \leq 0.001$ & $p_{2} \leq 0.001$ & $p_{2} \leq 0.001$ & $p_{2} \leq 0.001$ & $p_{2} \leq 0.001$ \\
& $p_{3} \leq 0.10$ & $p_{3} \leq 0.001$ & $p_{3} \leq 0.001$ & $p_{3} \leq 0.001$ & $p_{3} \leq 0.01$ & $p_{3} \leq 0.05$ \\
& $p_{4}>0.10$ & $p_{4}>0.10$ & $p_{4}>0.10$ & $p_{4} \leq 0.05$ & $p_{4}>0.10$ & $p_{4}>0.10$ \\
\hline
\end{tabular}

Note. $p_{1}-$ significantly relative to the NC group;

$\mathrm{p}_{2}-$ significantly relative to the $\mathrm{PC}$ group;

$\mathrm{p}_{3}$ - significantly relative to the reference group (Arfazetin);

$\mathrm{p}_{4}-$ significantly relative to the reference group (Metformin).

should return to the initial level, or below [17]. This segment of the curve (after $60 \mathrm{~min}$ ) is called the hypoglycemic phase and reflects insulin production, and mainly depends on the functional state of the parasympathetic nervous system and the pancreas function. [10-11].

Thus, in the NC group, the glucose concentration increased by $48.6,56.6,40.4$, and $24.6 \%$ after $30,60,90$, and $120 \mathrm{~min}$, respectively, on an empty stomach and returned to baseline to $180 \mathrm{~min}$. On the other hand, in the PC group, blood glucose levels increased by $78.6,83.3,66.5$, and $46.5 \%$ after $30,60,90$, and $120 \mathrm{~min}$, respectively, and were $7.1 \%$ higher by 180 min relative to basal glycemia, which is significantly higher than the indicators of the NC group in all studied time intervals. Therefore, guided by the criteria for the diagnosis of DM 2 according to [15] the results of OGTT, it is possible to interpret the impaired glucose tolerance (prediabetes) in the PC group.

The introduction of the reference drug "Arfazetin" restrained the increase in glycemia by $10.9,7.5$, $13.7,13.1 \%$ after $30,60,90,120$ minutes relative to the PC group and returned to baseline by 180 minutes. However, analyzing the absolute values, the blood glucose level for 120 min was high, which according to [14], is interpreted as impaired glucose tolerance (prediabetes) due to the effect of this drug is not enough to curb the development of glycemia in experimental diabetes.

According to [14] the first-line drug for treating patients with DM 2 and overweight is metformin, which remains the most studied in terms of efficacy and safety of monotherapy. Under OGTT in the group, which received metformin, the following results were obtained: the glycemia after 30,60 ,
90,120 min was significantly lower by $24.4,22.8$, 19.0, $17.3 \%$, respectively, than the PC group and did not differ from the indicators of the NC group.

In the experimental group, which received phytocomposition, the glucose concentration was lower than the PC group by $21.4,24.8,26.7,18.9$, $7.8 \%$ after $30,60,90,120$, and $180 \mathrm{~min}$, respectively, which significantly exceeded the effect "Arfazetin" for 30, 60, $90 \mathrm{~min}$, and did not significantly differ from the indicators of the NC group and the reference group, which received metformin, at all studied periods.

Based on OGTT results, glycemic coefficients were calculated, which are used to interpret glycemic curves and are presented in Figure.

After analyzing the coefficients, it can be seen that in the PC group Baudouin's and Rafalsky's coefficients exceeded the norm. Also, it was found that the same coefficients exceeded the norm in the reference group, which received Arfazetin, which indicates inadequate absorption of glucose from the intestine and insufficient release of insulin in response to "glucose load" [10-11]. The same indicators corresponded to the norm in the reference group, which received metformin and experimental group, which received phytocomposition. Sokolnikov's coefficient, which reflects a violation of the relationship between glucose resorption and utilization, indicates insufficient insulin release and confirms the lack of an adequate hypoglycemic phase [10-11].

Short insulin test allows assessing the sensitivity of both the liver and peripheral tissues to the action of insulin, given the inhibition of glucose production in the liver and increased utilization of glucose by muscle due to the effect of the hormone 


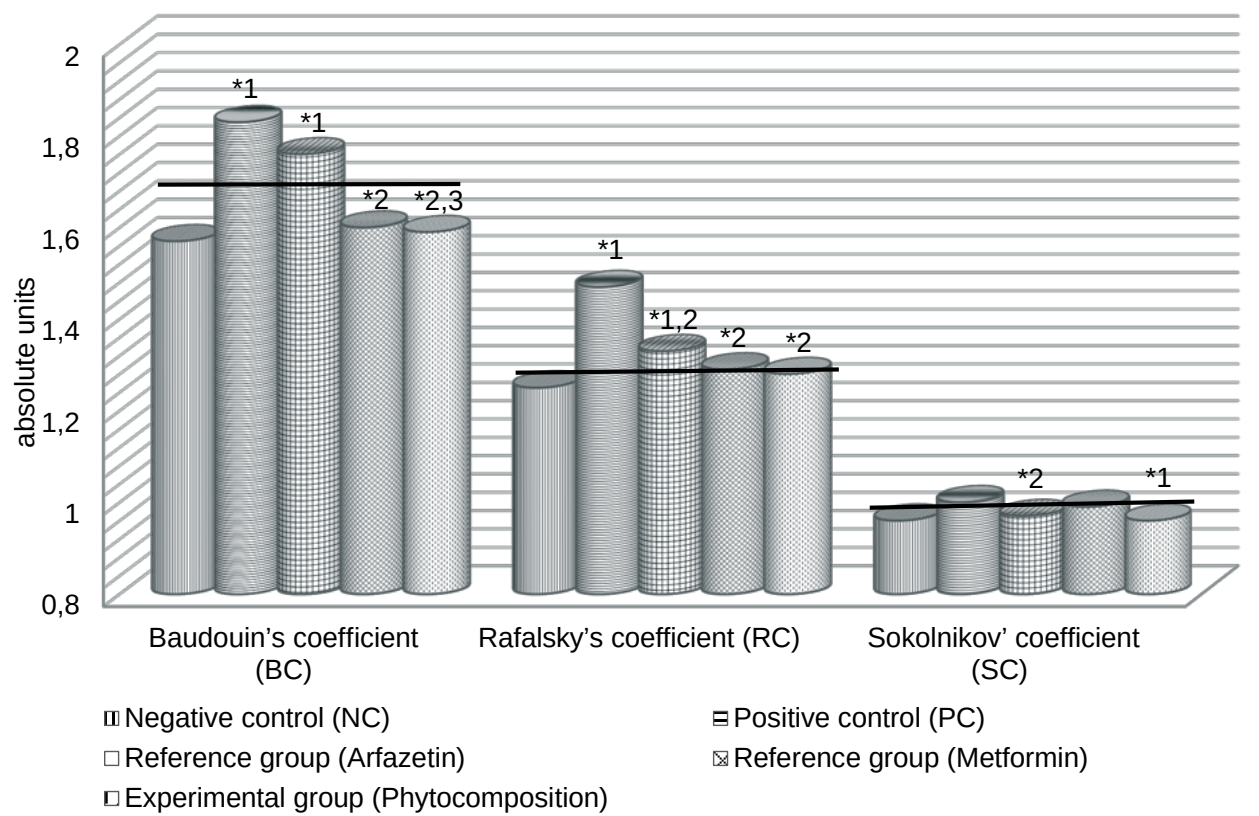

Figure. Functional glycemic coefficients obtained from oral glucose tolerance test (OGTT).

Note. The line marks the upper limit of the norm for each coefficients.

* 1 - significantly relative to the NC group;

* 2 - significantly relative to the PC group;

* 3 - significantly relative to the reference group (Arfazetin);

* 4 - significantly relative to the reference group (Metformin).

[7]. The test (Table 3) revealed a significant decrease in insulin sensitivity by $23.0 \%$ in the PC group relative to the NC group, which confirms IR development. In the reference groups, which received Arfazetin and metformin, insulin sensitivity significantly increased by 8.2 and $11.4 \%$ respectively, relative to the PC group.

In the experimental group, which received phytocomposition, the insulin sensitivity coefficient was $45.7 \%$, which is $16.2 \%$ higher than in the PC group, significantly higher than the indicator in the reference group, which received Arfazetin, and did not differ statistically from the reference group, which received metformin and NC group. This indicates inhibition of IR development under the influence of phytocomposition at the level of the effect of metformin.

The last stage of research was to study the effect of phytocomposition on the development of adrenaline hyperglycemia, which is to activate

Table 3 - The results of short insulin test

\begin{tabular}{||l|c|c||}
\hline \multicolumn{1}{|c|}{ Experimental group } & $\begin{array}{c}\text { The basal glycemia, } \\
\mathrm{mmol} / \mathrm{l}\end{array}$ & $\begin{array}{c}\text { The blood glucose concentration } \\
\text { after } 30 \mathrm{~min}, \mathrm{mmol} / \mathrm{l}\end{array}$ \\
\hline Negative control (NC) & $4.78 \pm 0.08$ & $2.26 \pm 0.07$ \\
\hline Positive control (PC) & $5.98 \pm 0.08$ & $4.21 \pm 0.16$ \\
& $\mathrm{p}_{1} \leq 0.001$ & $\mathrm{p}_{1} \leq 0.001$ \\
\hline Reference group (Arfazetin) & $5.23 \pm 0.10$ & $3.25 \pm 0.09$ \\
& $\mathrm{p}_{1} \leq 0.01$ & $\mathrm{p}_{1} \leq 0.001$ \\
& $\mathrm{p}_{2} \leq 0.001$ & $\mathrm{p}_{2} \leq 0.001$ \\
\hline Reference group (Metformin) & $5.36 \pm 0.11$ & $3,17 \pm 0.18$ \\
& $\mathrm{p}_{1} \leq 0.001$ & $\mathrm{p}_{1} \leq 0.001$ \\
& $\mathrm{p}_{2} \leq 0.001$ & $\mathrm{p}_{2} \leq 0.001$ \\
\hline Experimental group & $5.12 \pm 0.09$ & $2,77 \pm 0.11$ \\
(Phytocomposition) & $\mathrm{p}_{1} \leq 0.05$ & $\mathrm{p}_{1} \leq 0.01$ \\
& $\mathrm{p}_{2} \leq 0.001$ & $\mathrm{p}_{2} \leq 0.001$ \\
& $\mathrm{p}_{3}>0.10$ & $\mathrm{p}_{3} \leq 0.01$ \\
& $\mathrm{p}_{4}>0.10$ & $\mathrm{p}_{4} \leq 0.10$ \\
\hline
\end{tabular}

Note. $\mathrm{p}_{1}$ - significantly relative to the NC group;

$\mathrm{p}_{2}$ - significantly relative to the PC group;

$\mathrm{p}_{3}$ - significantly relative to the reference group (Arfazetin);

$\mathrm{p}_{4}$ - significantly relative to the reference group (Metformin). 
under its influence glycogenolysis in the liver. The degree and rate of rising of the glycemic curve after adrenaline injection characterize the state of carbohydrate reserves in the body and can be used as an indicator of impaired carbohydrate metabolism $[7,13]$. The results of adrenaline test are presented in Table 4.

The concentration of glucose in the blood in the NC group increased by 46.8 and $81.7 \%$ after 30 and 90 min after the introduction of adrenaline relative to basal glycemia. On the contrary, in the $\mathrm{PC}$ group, there was a statistically more significant increase in glycemia compared with NC group by 50.3 and $75.9 \%$, which indicates a substantial in- crease in sensitivity to the stimulating effect of adrenaline on gluconeogenesis in induced IR and once again confirms the profound deviations in carbohydrate metabolism under the influence of dexamethasone [12].

In the reference group, which received Arfazetin, glycemia was significantly lower by 31.5 and $61.6 \%$ after 30 and $90 \mathrm{~min}$, respectively, from the beginning of adrenaline test, and at 90 min corresponded to NC group. In the reference group, which received metformin, the glycemic level was significantly lower than in the PC group by $61.4,98.3 \%$, and by 11.1, $22.4 \%$ from the NC group in 30 and 90 min, respectively, after the injection of adrenaline.

Table 4 - The results of adrenaline test

\begin{tabular}{||l|c|c|c|}
\hline \multirow{2}{*}{ Experimental group } & The basal glycemia, & \multicolumn{2}{|c|}{ The blood glucose concentration, $\mathrm{mmol} / \mathrm{I}$} \\
\cline { 3 - 4 } & $\mathrm{mmol} / \mathrm{l}$ & After $30 \mathrm{~min}$ & After $90 \mathrm{~min}$ \\
\hline Negative control (NC) & $4.41 \pm 0.09$ & $6.46 \pm 0.13$ & $8.00 \pm 0.15$ \\
\hline Positive control (PC) & $5.63 \pm 0.11$ & $11.07 \pm 0.17$ & $14.48 \pm 0.25$ \\
& $\mathrm{p}_{1} \leq 0.001$ & $\mathrm{p}_{1} \leq 0.001$ & $\mathrm{p}_{1} \leq 0.001$ \\
\hline Reference group & $5.47 \pm 0.07$ & $9.05 \pm 0.25$ & $10.71 \pm 0.36$ \\
(Arfazetin) & $\mathrm{p}_{1} \leq 0.001$ & $\mathrm{p}_{1} \leq 0.001$ & $\mathrm{p}_{1} \leq 0.001$ \\
& $\mathrm{p}_{2}>0.10$ & $\mathrm{p}_{2} \leq 0.001$ & $\mathrm{p}_{2} \leq 0.001$ \\
\hline Reference group & $5.05 \pm 0.09$ & $6.87 \pm 0.30$ & $8.03 \pm 0.16$ \\
(Metformin) & $\mathrm{p}_{1} \leq 0.001$ & $\mathrm{p}_{1}>0.10$ & $\mathrm{p}_{1}>0.10$ \\
& $\mathrm{p}_{2} \leq 0.001$ & $\mathrm{p}_{2} \leq 0.001$ & $\mathrm{p}_{2} \leq 0.001$ \\
\hline Experimental group & $5.19 \pm 0.08$ & $7.98 \pm 0.20$ & $9.73 \pm 0.26$ \\
(Phytocomposition) & $\mathrm{p}_{1} \leq 0.001$ & $\mathrm{p}_{1 \leq 0} \leq .001$ & $\mathrm{p}_{1} \leq 0.001$ \\
& $\mathrm{p}_{2} \leq 0.01$ & $\mathrm{p}_{2} \leq 0.001$ & $\mathrm{p}_{2} \leq 0.001$ \\
& $\mathrm{p}_{3} \leq 0.05$ & $\mathrm{p}_{3} \leq 0.01$ & $\mathrm{p}_{3} \leq 0.05$ \\
& $\mathrm{p}_{4}>0.10$ & $\mathrm{p}_{4} \leq 0.01$ & $\mathrm{p}_{4} \leq 0.001$ \\
\hline
\end{tabular}

The studied phytocomposition inhibited the development of glycemia by $42.9,70.2 \%$ after 30 and $90 \mathrm{~min}$, respectively, relative to the $\mathrm{PC}$ group, which corresponds to the indicators of NC group and reference group, which received Arfazetin. Still, this decrease is not enough to exceed the effect of metformin.

CONCLUSIONS. 1. Basal glycemia after modeling insulin resistance in the experimental group, which received the phytocomposition, was significantly lower by $19.0 \%$ from the positive control group and did not differ from the activity of metfor$\min$.

2. During the oral glucose tolerance test, the phytocomposition significantly inhibited the growth of glycemia in all studied periods relative to the indicators of the positive control group. However, functional glycemic coefficients, which were ob- tained based on the same test data, did not exceed the norm.

3. Insulin sensitivity under the influence of phytomedicine increased by $16.2 \%$ above the positive control group, indicating inhibition of insulin resistance development under its influence.

4. The studied phytocomposition inhibited the development of adrenaline glycemia by 42.9 , $70.2 \%$ after 30 and $90 \mathrm{~min}$, respectively, relative to the positive control group, which corresponds to the indicators of the negative control group and reference group, which received Arfazetin, but this decrease is not enough to exceed the effect of metformin.

5. The obtained results indicate that the studied phytocomposition inhibits the development of insulin resistance and carbohydrate tolerance in the conditions of insulin resistance caused by the introduction of dexamethasone. 


\section{LIST OF LITERATURE}

1. IDF diabetes atlas - 9th edition [Electronic resource]-Access mode : http://www.diabetesatlas.org/.

2. Посохова К. А. Вплив кверцетиновмісних сполук на стан міокарда при цукровому діабеті 2 типу / К. А. Посохова, І. П. Стечишин, В.В.Підгірний // Здобутки клініч. і експерим. медицини. - 2014. - № 2. С. $17-21$.

3. Устінов О. В. Алгоритм дії лікаря і керівника закладу охорони здоров'я при наданні медичної допомоги пацієнтам із цукровим діабетом 2-го типу [Електронний ресурс] / О. В. Устінов // Укр. мед. часоп. 2015. - Режим доступу до ресурсу : https://www.umj. com.ua/wp/wp-content/uploads/2015/01/Diabet_2.pdf/.

4. Стечишин I. П. Антиоксидантна та гіпоглікемічна активність біофрлавоноїдів за цукрового діабету II типу / І. П. Стечишин, А. І. Дуб // Фармакологія та лікар. токсикологія. - 2017. - № 6. - С. 15-22.

5. Вивчення гіпоглікемічної дії фрітозасобу, що містить сухі екстракти з листя шовковиці білої, стулок квасолі звичайної і пагонів чорниці звичайної / А. І. Дуб, І. М. Кліщ, Л. В. Вронська, І. П. Стечишин // Мед. та клініч. хімія. - 2018. - 20, № 3 (76). - С. 43-49.

6. Вплив фрітокомпозиції на ліпідний спектр кров на моделі твінової гіперліпідемії у щурів / А. І. Дуб, І. М. Кліщ, Л. В. Вронська, І. П. Стечишин // Фармакологія і лікар. токсикологія. -2018. - № 4-5. - С. 32-37.

7. Доклинические исследования лекарственных средств : метод. рек. / под ред. А. В. Стефанова. - К. : Авиценна, 2002. - 528 с.

8. Activation of the gut calcium-sensing receptor by peptide agonists reduces rapid elevation of plasma glucose in response to oral glucose load in rats / M. Muramatsu, T. Hira, A. Mitsunaga [et al.] // American Journal of Physiology-Gastrointestinal and Liver Physiology. 2014. - 306 (12) - P. G1099-G1107.

9. Тишкова Я. В. Об использовании глюкозотолерантного и адреналинового тестов для определения фрункционального состояния печени при ее токси- ческом поражении / Я. В. Тишкова, О. В. Молотков, Э. Э. Ферамузова // Мед. вестн. Башкортостана. 2009. - 4, № 2. - С. 167-169.

10. Чазова И. Е. Метаболический синдром / И. Е. Чазова, В. Б. Мычка. - М. : Медиа Медика, 2004. - $144 \mathrm{c}$

11. Яровой С. П. Особенности углеводного обмена на фроне бронхиальной астмы и экстрасистолической аритмии у детей / С. П. Яровой // Таврический медико-биол. вестн. - 2012. - № 15. - С. 286-288.

12. Гіпоглікемічна активність трави портулаку городнього (Portulaca oleracea L.) в умовах дексаметазонового цукрового діабету у щурів / А. О. Кініченко, В. С. Клеванова, С. Д. Тржецинський, М. М. Малецький // Фармац. журн. - 2017. - № 2. - С. 62-68.

13. Клеванова В. С. Антидіабетичні властивості чорноголовника родовикового (Poterium sanguisorba L.) за умов дексаметазонового діабету в щурів / В. С. Клеванова, С. Д. Тржецинський, Г. О. Жернова // Фармакологія та лікар. токсикологія. - 2015. - № 1. С. $48-52$.

14. Про затвердження та впровадження медико-технологічних документів зі стандартизації медичної допомоги при цукровому діабеті 2 типу : наказ МО3 України від 21.12.2012 р. № 1118 [Електронний ресурс]. - Режим доступу до ресурсу : http://old.moz. gov.ua/ua/portal/dn 20121221 1118.html.

15. Аметов А. С. Современная интерпретация глюкозотолерантного теста (диагностический и прогностический подходы) / А. С. Аметов, Л. Л. Камынина // Эндокринология: Новости. Мнения. Обучение. 2012. - № 1. - С. 45-49.

16. Сорокман Т. В. Клинические и лабораторные критерии сахарного диабета 2-го типа у детей / Т. В. Сорокман, О. В. Макарова, В. Г. Остапчук // Междунар. эндокринол. журн. -2018. - № 14 (1). - С. 46-50.

17. Клінічна біохімія : підручник/ за ред. О. Я. Склярова. - К. : Медицина, 2006. - 432 с.

\section{REFERENCES}

1. IDF diabetes atlas - 9th edition. Retrieved from: http://www.diabetesatlas.org/

2. Posokhova, K.A., Stechyshyn, I.P., \& Pidhirnyy, V.V. (2014). Vplyv kvertsetynovmisnykh spoluk na stan miokarda pry tsukrovomu diabeti 2 typu [Influence of corvitin-containing compounds on myocardium status in diabetes mellitus type 2]. Zdobutky klinichnoi i eksperymentalnoi medytsyny - Achievements of Clinical and Experimental Medicine, 2, 17-21 [in Ukrainian].

3. Ustinov, O.V. (2015). Alhorytm dii likaria i kerivnyka zakladu okhorony zdorovia pry nadanni medychnoi dopomohy patsiientam iz tsukrovym diabetom 2-ho typu [Algorithm of action of a doctor and the head of a health care institution when providing medical care to patients with type 2 diabetes mellitus]. Ukrainskyi medychnyi chasopys - Ukrainian Medical Journal [Electronic resource]. Retrieved from: https://www.umj.com.ua/wp/ wp-content/uploads/2015/01/Diabet_2.pdf/[in Ukrainian].
4. Stechyshyn, I.P., \& Dub, A.I. (2017). Antyoksydantna ta hipohlikemichna aktyvnist bioflavonoidiv za tsukrovoho diabetu II typu [Antioxidant and hypoglycemic activity of bioflavanoids in type II diabetes mellitus]. Farmakolohiia ta likarska toksykolohiia - Pharmacology and Drug Toxicology, 6, 15-22 [in Ukrainian].

5. Dub, A.I., Klishch, I.M., Vronska, L.V., \& Stechyshyn, I.P. (2018). Vyvchennia hipohlikemichnoi dii fitozasobu, shcho mistyt sukhi ekstrakty z lystia shovkovytsi biloi, stulok kvasoli zvychainoi i pahoniv chornytsi zvychainoi [Research the hypoglicemic activity of the herbal remedy that contain dry extracts of white mulberry leaves, common bean shells and blueberry sprouts]. Medychna ta klinichna khimiia - Medical and Clinical Chemistry, 3, 43-49 [in Ukrainian].

6. Dub, A.I., Klishch, I.M., Vronska, LV., \& Stechyshyn, I.P. (2018). Vplyv fitokompozytsii na lipidnyi spektr krovi na modeli tvinovoi hiperlipidemii u shchuriv [An 
influence of new phytocomposition on the blood lipid spectrum under the model of hyperlipidemia in rats]. Farmakolohiia i likarska toksykolohiia - Pharmacology and Drug Toxicology, 4-5, 32-37 [in Ukrainian].

7. Stefanov, A.V. (Eds.). (2002). Doklinicheskie issledovaniya lekarstvennyh sredstv: Metodicheskie rekomendatsii [Preclinical studies of drugs: Methodological recommendations]. Kyiv: "Avitsenna" [in Russian].

8. Muramatsu, M., Hira, T., Mitsunaga, A., Sato, E., Nakajima, S., Kitahara, Y., ... \& Hara, H. (2014). Activation of the gut calcium-sensing receptor by peptide agonists reduces rapid elevation of plasma glucose in response to oral glucose load in rats. American Journal of Physiology-Gastrointestinal and Liver Physiology, 306 (12), G1099-G1107.

9. Tishkova, Ya.V., Molotkov, O.V., \& Feramuzova, E.E. (2009). Ob ispolzovanii glyukozotolerantnogo i adrenalinovogo testov dlya opredeleniya funktsionalnogo sostoyaniya pecheni pri ee toksicheskom porazhenii [On the use of glucose tolerance and adrenaline tests to determine the functional state of the liver in case of its toxic damage]. Meditsinskiy vestnik Bashkortostana Medical Bulletin of Bashkortostan, 4 (2), 167-169 [in Russian].

10. Chazova, I.E., \& Mychka, V.B. (2004). Metabolicheskiy sindrom [Metabolic syndrome]. Moscow: Media Medika [in Russian].

11. Yarovoy, S.P. (2012). Osobennosti uglevodnogo obmena na fone bronhialnoy astmy i ekstrasistolicheskoy aritmii u detey [Features of carbohydrate metabolism against the background of bronchial asthma and extrasystolic arrhythmia in children]. Tavricheskiy medikobiologicheskiy vestnik - Tavrichesky Medical and Biological Bulletin, 15, 286-288 [in Russian].

12. Kinichenko, A.O., Klevanova, V.S., Trzhetsynskyi, S.D., \& Maletskyi, M.M. (2017). Hipohlikemichna aktyvnist travy portulaku horodnoho (Portulaca oleracea L.) v umovakh deksametazonovoho tsukrovoho diabetu u shchuriv [Hypoglycemic properties of Portulaca oleracea herb in the experimental conditions of dexamethasone diabetes mellitus in rats]. Farmatsevtychnyi zhurnal - Pharmaceutical Journal, 2, 62-68 [in Ukrainian].

13. Klevanova, V.S., Trzhetsynskyi, S.D. \& Zhernova, H.O. (2015). Antydiabetychni vlastyvosti chornoholovnyka rodovykovoho (Poterium sanguisorba L.) za umov deksametazonovoho diabetu v shchuriv [Antidiabetic properties of Poterium sanguisorba $L$. in dexamethasone diabetes in rats]. Farmakolohiia ta likarska toksykolohiia Pharmacology and Drug Toxicology, 1, 48-52 [in Ukrainian].

14. Nakaz MOZ Ukrainy vid 21.12.2012 № 1118 “Pro zatverdzhennia ta vprovadzhennia medyko-tekhnolohichnykh dokumentiv zi standartyzatsii medychnoi dopomohy pry tsukrovomu diabeti 2 typu" [Order of the Ministry of Health of Ukraine dated 21.12.2012 № 1118 "On approval and implementation of medical and technological documents for the standardization of medical care for type 2 diabetes mellitus"]. Retrieved from: http://old.moz. gov.ua/ua/portal/dn_20121221_1118.html [in Ukrainian].

15. Ametov, A.S., \& Kamynina, L.L. (2012). Sovremennaya interpretatsiya glyukozotolerantnogo testa (diagnosticheskiy i prognosticheskiy podhody) [Modern interpretation of glucose tolerance test (diagnostic and prognostic approaches)]. Endokrinologiya: Novosti. Mneniya. Obuchenie - Endocrinology: News. Opinions. Training, 1, 45-49 [in Russian].

16. Sorokman, T.V., Makarova, O.V., \& Ostapchuk, V.G. (2018). Klinicheskie i laboratornye kriterii saharnogo diabeta 2-go tipa u detey [Clinical and laboratory criteria for type 2 diabetes mellitus in children]. Mezhdunarodnyy endokrinologicheskiy zhurnal - International Endocrinological Journal, 14 (1), 46-50 [in Russian].

17. Skliarov, O.la. (Eds.). (2006). Klinichna biokhimiia: Pidruchnyk [Clinical Biochemistry: Textbook]. Kyiv: Medytsyna [in Ukrainian].

\section{ДОСЛІДЖЕННЯ СПЕЦИФІЧНОЇ АКТИВНОСТІ ФІТОКОМПОЗИЦІЇ ПРИ ІНСУЛІНОРЕЗИСТЕНТНОСТІ, СПРИЧИНЕНІЙ ДЕКСАМЕТАЗОНОМ}

\section{Резюме}

Вступ. Цукровий діабет 2 типу (ЦД 2) останнім часом набуває епідемічного характеру поширення. У світі налічується приблизно 463 млн хворих, а за прогнозами експертів Міжнародної фредерації діабету, до 2045 р. передбачається збільшення їх кількості до 629 млн осіб, з яких понад 90 \% припадатиме на ЦД 2. Незважаючи на значний прогрес у вивченні патогенезу ЦД, широкий спектр протидіабетичних препаратів, це захворювання залишається гострою медичною та соціальною проблемою.

Мета дослідження - вивчити специфрічну активність фрітокомпозиції, що містить сухі екстракти листя шовковиці білої (Morus alba L.), стулок квасолі звичайної (Phaseolus vulgaris L.) та пагонів чорниці звичайної (Vaccinium myrtillus L.), за умов експериментальної моделі інсулінорезистентності, спричиненоі дексаметазоном. 


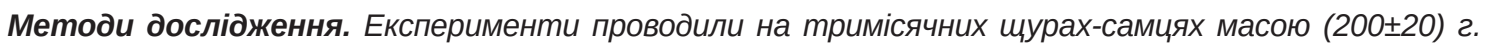
Піддослідних тварин розподілили на такі групи: негативний та позитивний контроль, 2 референс-групи, які отримували арфразетин і метформін відповідно, й експериментальну групу, яка одержувала фрітокомпозицію. Інсулінорезистентність моделювали шляхом внутрішньом'язового введення глюкокортикостероїду дексаметазону (0,125 мг/кг щодня впродовж 13 днів уранці). Стан вуглеводного гомеостазу оцінювали за змінами базальної глікемії та за допомогою орального тесту толерантності до глюкози, короткого інсулінового й адреналінового тесту. Також було розраховано фрункціональні глікемічні коефріцієнти. Cтатистичну обробку проводили за допомогою комп'ютерних програм IBM SPSS Statistics v.10.1 ma MS Excel 2010.

Результати й обговорення. Глікемія натще після моделювання інсулінорезистентності в експериментальній групі, яка отримувала фрітокомпозицію, була значно нижчою - на 19,0% від групи позитивного контролю і не відрізнялася від активності метформіну. Під час орального тесту толерантності до глюкози фрітокомпозиція суттєво пригнічувала зростання глікемії в усі досліджувані періоди щодо показників групи позитивного контролю. Функціональні глікемічні коефріцієнти, одержані на основі даних тесту, не перевищували норми. Чутливість до інсуліну під впливом фрітокомпозиції збільшилась на 16,2 \% порівняно з групою позитивного контролю, що свідчило про пригнічення розвитку інсулінорезистентності під його впливом. Досліджувана фрітокомпозиція пригнічувала розвиток адреналінової глікемії на 42,9 і 70,2 \% через 30 та 90 хв відповідно щодо групи позитивного контролю, що відповідало показникам групи негативного контролю та рефреренс-групи, яка отримувала арфазетин, але цього зниження недостатньо, щоб перевищити ефрект меторорміну.

Висновок. Отримані результати вказують на те, що досліджувана фрітокомпозиція пригнічує розвиток інсулінорезистентності та толерантності до вуглеводів за умов інсулінорезистентності, спричиненої введенням дексаметазону.

КЛЮЧОВІ СЛОВА: цукровий діабет; інсулінорезистентність; фрітокомпозиція; гіпоглікемічна активність; шовковиця біла; квасоля звичайна; чорниця звичайна.

А. И. Дуб, И. Н. Клищ, Л. В. Вронска, И. П. Стечишин ТЕРНОПОЛЬСКИЙ НАЦИОНАЛЬНЫЙ МЕДИЦИНСКИЙ УНИВЕРСИТЕТ ИМЕНИ И. Я. ГОРБАЧЕВСКОГО МОЗ УКРАИНЫ

\section{ИССЛЕДОВАНИЕ СПЕЦИФИЧЕСКОЙ АКТИВНОСТИ ФИТОКОМПОЗИЦИИ ПРИ ИНСУЛИНОРЕЗИСТЕНТНОСТИ, ВЫЗВАННОЙ ДЕКСАМЕТАЗОНОМ}

\section{Резюме}

Вступление. Сахарный диабет 2 типа (СД 2) в последнее время приобретает эпидемический характер распространения. В мире насчитывается примерно 463 млн больных, а по прогнозам экспертов Международной фредерации диабета, в 2045 г. предполагается увеличение их количества до 629 млн человек, из которых более 90 \% будет приходиться на СД 2. Несмотря на значительный прогресс в изучении патогенеза СД, широкий спектр противодиабетических препаратов, это заболевание остается острой медицинской и социальной проблемой.

Цель исследования - изучить специфрическую активность фритокомпозиции, содержащей сухие экстракты листьев шелковицы белой (Morus alba L.), створок фрасоли обыкновенной (Phaseolus vulgaris L.) и побегов черники обыкновенной (Vaccinium myrtillus L.), в условиях экспериментальной модели инсулинорезистентности, вызванной дексаметазоном.

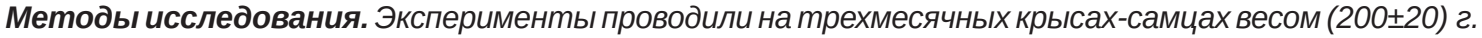
Подопытных животных распределили на следующие группы: негативный и позитивный контроль, 2 рефреренс-группы, получавшие арфразетин и меторормин соответственно, и экспериментальную группу, которая получала фитокомпозицию. Инсулинорезистентность моделировали путем внутримышечного введения глюкокортикостероида дексаметазона (0,125 мг/ка ежедневно в течение 13 дней утром). Состояние углеводного гомеостаза оценивали по изменениям базальной гликемии и с помощью орального теста толерантности к глюкозе, короткого инсулинового и адреналинового теста. Также были рассчитаны фрункциональные гликемические коэффициенты. Статистическую обработку проводили с помощью компьютерных программ IBM SPSS Statistics v.10.1 и MS Excel 2010. 
Результаты и обсуждение. Гликемия натощак после моделирования инсулинорезистентности в экспериментальной группе, получавшей фритокомпозицию, была значительно ниже - на 19,0 \% от группы положительного контроля и не отличалась от активности меторормина. Во время орального теста толерантности к глюкозе фритокомпозиция существенно подавляла возрастание гликемии во все исследуемые периоды относительно показателей группы положительного контроля. Функциональные гликемические коэфрфициенты, полученные на основе данных теста, не превышали нормы. Чувствительность к инсулину под влиянием фритокомпозиции увеличилась на 16,2 \% по сравнению с группой положительного контроля, что свидетельствовало об угнетении развития инсулинорезистентности под его влиянием. Исследуемая фритокомпозиция подавляла развитие адреналиновой гликемии на 42,9 и 70,2 \% через 30 и 90 мин соответсвенно относительно группы положительного контроля, что соответствовало показателям группы отрицательного контроля и рефреренс-группы, получавшей арфазетин, но этого снижения недостаточно, чтобы превысить эфрфект метформина.

Вывод. Полученные результаты указывают на то, что исследуемая фритокомпозиция подавляет развитие инсулинорезистентности и толерантности куглеводам в условиях инсулинорезистентности, вызванной введением дексаметазона.

КЛЮЧЕВЫЕ СЛОВА: сахарный диабет; инсулинорезистентность; фритокомпозиция; гипогликемическая активность; шелковица белая; фасоль обыкновенная; черника обыкновенная.

Received 17.03.21

Address for correspondence: A. I. Dub, I. Horbachevsky Ternopil National Medical University, Maidan Voli, 1, Ternopil, 46001, Ukraine, e-mail: dub_aih@tdmu.edu.ua. 